\title{
Systematic Review on the Incidence of Bisphosphonate Related Osteonecrosis of the Jaw in Children Diagnosed with Osteogenesis Imperfecta
}

\author{
Anusha Adeline Hennedige ${ }^{1,2}$, Jap Jayasinghe ${ }^{1}$, Janette Khajeh ${ }^{1}$, Tatiana V. Macfarlane ${ }^{1}$ \\ ${ }^{1}$ University of Aberdeen Dental School, Aberdeen, United Kingdom. \\ ${ }^{2}$ Aberdeen Royal Infirmary, Oral and Maxillofacial Department, United Kingdom.
}

\author{
Corresponding Author: \\ Anusha Adeline Hennedige \\ University of Aberdeen Dental School \\ Foresterhill Campus \\ Cornhill Road, Aberdeen AB25 2ZR \\ United Kingdom \\ E-mail: anushahennedige@nhs.net \\ Phone: +44 (0)1224 272000
}

\begin{abstract}
Objectives: To conduct a systematic review of epidemiological literature to determine the incidence of bisphosphonate related osteonecrosis of the jaw occurring either spontaneously or after dental surgery, in children and adolescents diagnosed with osteogenesis imperfecta.

Material and Methods: MEDLINE, HMIC and EMBASE were used to search for English-language articles published from 1946 - 2013. Inclusion criteria consisted of population based studies of children and adolescents (24 years and younger) diagnosed with osteogenesis imperfecta, only studies which included a dental examination, and patients treated with intravenous bisphosphonates were included. Articles were excluded if patients had any other co-morbidity which could affect osteonecrosis of the jaw, and those which treated patients with oral bisphosphonates only.

Results: Five studies consisting of four retrospective cohort studies and one case series were identified. Study populations ranged from 15 to 278 patients and number of subjects with osteogenesis imperfecta ranged from 15 to 221 . Mean duration of intravenous bisphosphonate use ranged from 4.5 to 6.8 years. All patients were clinically examined and no patients were found to have osteonecrosis of the jaw.

Conclusions: There is no evidence to support hypothesis of causal relationship between bisphosphonates and osteonecrosis of the jaw in children and adolescents with osteogenesis imperfecta. More prospective studies on bisphosphonate use in osteogenesis imperfecta needs to be carried out.
\end{abstract}

Keywords: osteonecrosis; jaw; osteogenesis imperfecta; children; bisphosphonates.

Accepted for publication: 16 November 2013

To cite this article:

Hennedige AA, Jayasinghe J, Khajeh J, Macfarlane TV. Systematic Review on the Incidence of Bisphosphonate Related Osteonecrosis of the Jaw in Children Diagnosed with Osteogenesis Imperfecta.

J Oral Maxillofac Res 2013;4(4):e1

URL: http://www.ejomr.org/JOMR/archives/2013/4/e1/v4n4e1ht.pdf

doi: $10.5037 /$ jomr.2013.4401 


\section{INTRODUCTION}

Bisphosphonates (BP) are widely used for a range of conditions including osteoporosis, Paget's disease, multiple myeloma, hypercalcaemia of malignancy and bone metastasis of breast and prostate cancer. Another indication of intravenous (IV) BP is in the treatment of children and adolescents with osteogenesis imperfecta (OI). OI is the most common genetic bone disorder with an estimated prevalence of between 1 in 10,000 and 1 in 20,000 births [1]. The majority of OI is caused by a genetic defect in the structural protein type 1 collagen. There are 8 different types of OI, Type 1 being the most common. IV BP is currently the mainstay of treatment of OI with many studies revealing a significant rise in the bone mass density and decrease risk of clinical fractures [2-4].

BP have been related to osteonecrosis of the jaw (ONJ) and is commonly known as bisphosphonaterelated osteonecrosis of the jaw (BRONJ) in the adult population [5]. Their inhibition of osteoclast-mediated bone resorption with subsequent decrease in bone turnover and anti-angiogenic characteristics are believed to contribute to the development of BRONJ $[\underline{5}, \underline{6}]$. There have been numerous well documented reviews which have showed the role of IV BP in contributing to ONJ mainly in patients undergoing bisphosphonate treatment for malignant disease or osteoporosis [5-8]. However, currently, there is no documented cause and effect relationship between IV BP and ONJ as many confounding factors exist [ $\underline{5-7]}$. These include older age, periodontal disease, glucocorticoid treatment for chronic conditions and oestrogen treatment which are mostly associated with the adult population [8]. These confounding factors are believed to be risk factors in developing ONJ. However, in the majority of cases, a precipitating factor is usually required and this is in most cases an invasive dental procedure [8-10]. However, ONJ is also known to occur spontaneously with studies quoting between $16-40 \%$ of $\mathrm{ONJ}$ occurring without any identifiable precipitating factor $[9,10]$. The most common precipitating factor is oral surgery or extraction of teeth which leaves a nonhealing area of exposed bone.

In light of the uncertainty surrounding IV BP, ONJ and concomitant risk factors, dentists have questioned how to manage the care of patients receiving IV BP therapy. According to the Scottish Dental Clinical Effectiveness Programme (SDCEP) guidelines on management of patients who were prescribed bisphosphonates [11], patients diagnosed with OI are placed in the "high risk" category of developing ONJ. This places OI patients alongside patients with a previous diagnosis of BRONJ, those with malignant conditions being managed with $\mathrm{BP}$, other non-malignant conditions affecting bone (e.g. Paget's disease), concurrent use of systemic corticosteroids or other immunosuppressant, those with a coagulopathy or undergoing chemotherapy or radiotherapy. Placing a patient in the high risk category would alert a dentist to refer the patient to the local Maxillofacial or Oral Surgery Department prior to any dental treatment which may impact on bone, including extractions. Hence patients are not treated in the primary care setting and are referred on to secondary or tertiary care services. The "low risk" category includes patients about to start BP therapy for any condition, or patients taking BP to prevent or manage osteoporosis (without higher risk factors). "Low risk" patients can be treated in the primary care sector with suggestions to carry out extractions as "atraumatically" as possible, avoid raising flaps and achieve good haemostasis with review of healing at four weeks. Hence, classifying patients in the "high risk" category leads to a delay in their management and places increasing pressure on secondary and/or tertiary care services.

The aim of this review is to ascertain the need for OI patients to be placed in the high risk category when no other concomitant risk factors exist [11] and ascertain the incidence of BRONJ in OI paediatric patients occurring spontaneously or after dental surgery.

\section{MATERIAL AND METHODS}

The study was registered with Prospero - The International Prospective Register of Systematic Reviews: https://www.crd.york.ac.uk/PROSPERO/.

We followed the Cochrane Collaboration PRISMA Statement (Preferred Reporting Items for Systematic Reviews and Meta-Analyses) [12] for reporting observational studies and meta-analysis of observational studies and also considered the Consensus Statement.

\section{Types of publication}

The review included studies on humans published in the English language. Letters, editorials, $\mathrm{PhD}$ theses and abstracts were excluded.

\section{Types of studies}

The review included any published observational studies (cross-sectional surveys, cohort and case-control studies), literature reviews, clinical trials of treatment and case series. Experimental laboratory studies, single case reports were excluded. 


\section{Population}

Only studies of children and young adults (24 years and younger) diagnosed with OI were selected.

\section{Disease definition}

Only studies which included a dental examination by a clinician who was capable of diagnosing ONJ were included. The disease definition included an area of exposed bone which was non-healing for 6 - 8 weeks (as recommended by the American Association of Oral and Maxillofacial Surgery [13]]). Studies where no clinical examination was undertaken were not included.

\section{Literature search strategy (Figure 1)}

The literature search aimed to identify original studies conducted after 1946. Relevant studies were identified by searching the following data bases: Ovid MEDLINE ${ }^{\circledR}$ (1946 - May Week 5 2013); EMBASE (1974 - 2013 Week 23) and HMIC (1979 - November 2012).

Ovid MEDLINE $^{\circledR}$ (1946 - May Week 5 2013) was checked using the search terms osteonecrosis or osteochemonecrosis or necrosis or non-healing bone or jaw disease combined with jaw or mandible combined with bisphosphonates or diphosphonates or zolendronate or pamidronate combined with children or adolescents or teenagers or child or childhood or paediatric.

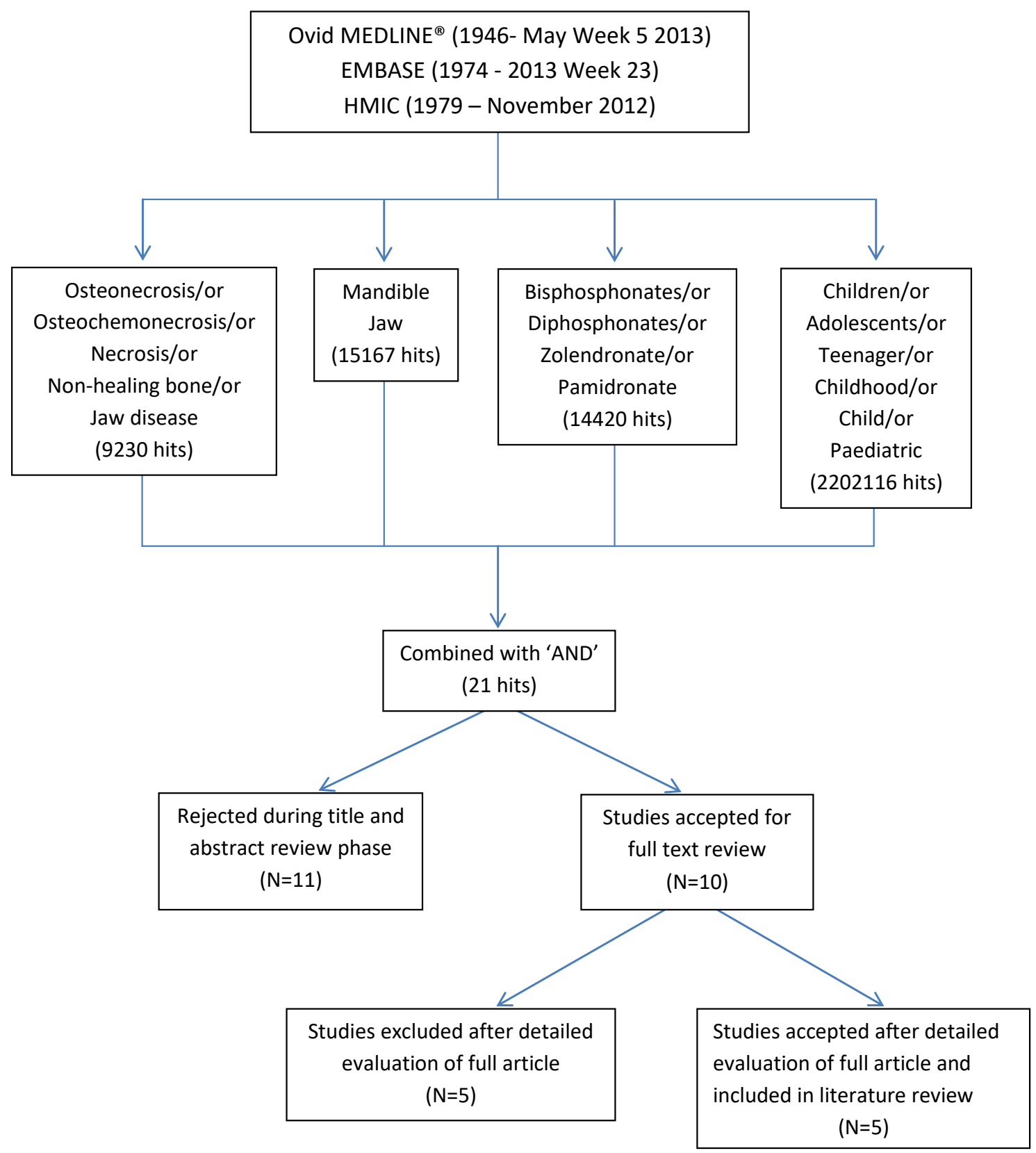

Figure 1. Flow of information through the different phases of the systematic review. 
EMBASE (1974 - 2013 Week 23) and HMIC (1979 November 2012) were checked using a search strategy to resemble the MEDLINE search strategy as closely as possible. The results of the database searches were combined and duplicate articles were excluded.

References of all relevant studies were screened to discover additional relevant publications and to improve the sensitivity of the search. Each search was independently carried out by 2 authors. Full reports were obtained for all the studies that were deemed eligible for inclusion in this paper.

\section{Inclusion and exclusion criteria}

For inclusion in the review, published articles had to meet all of the following criteria: English language; the population consisted of young adults children/ adolescents below the age of 24 years old; male or female diagnosed with OI only; patients received IV BP for the treatment of OI only; the IV BP given had to be a nitrogen-containing BP; BP was administered IV; the characteristics of BP treatment were recorded (dose, duration of treatment and mode of administration); clinical features of ONJ (site, signs, symptoms); incidence of ONJ or any associated complications.

Articles were rejected if patients had any other comorbidity which could affect $\mathrm{ONJ}$; adults; patients on oral BP only.

Two articles included patients who were diagnosed with other bone disorders which required management with IV BP. Only the data from patients diagnosed with OI and treated with BP were extrapolated from these studies where possible.

\section{Article review and data abstraction}

Abstracts of the studies identified using the search strategy, were reviewed, and the full text was obtained for those that met the inclusion criteria.
The review process was repeated for the full articles, and the following data were extracted from the accepted articles onto a standardized spread sheet:

1. Study design;

2. Number of subjects in study;

3. Number of subjects with OI;

4. Age range, mean and/or median age of subjects;

5. Sex distribution of subjects;

6. IV BP used;

7. Mean duration of IV BP use;

8. Range of duration of use of IV BP;

9. Mean cumulative dose of IV BP;

10. Range of cumulative dose of IV BP;

11. Method of detecting ONJ;

12. Number of patients who had undergone dental surgery since commencing IV BP therapy.

\section{Quality assessment}

All the included studies were subjected to a recognised quality analysis method - Strengthening the Reporting of Observational Studies in Epidemiology (STROBE) Initiative [14].

STROBE consists of a checklist of 22 items that relate to the title, abstract, introduction, methods, results, and discussion sections of articles. They were developed based on recommendations on what should be included in an accurate and complete report of an observational study.

\section{RESULTS}

A total of 5 studies [1,15-18] were included in this review (Figure 1). The studies were from Italy, Australia, Sweden and Canada. All results are presented in Tables 1,2 and 3. They were conducted between 2008 and 2012. All studies investigated the incidence of ONJ in children with OI. Four studies [1, 15-17]

Table 1. Description of included studies: IV bisphosphonates, osteogenesis imperfecta patients and osteonecrosis of the jaw

\begin{tabular}{ccccccccccc}
\hline & \multicolumn{2}{c}{ Study } & \multicolumn{3}{c}{ Demographics } & \multicolumn{2}{c}{ Sex } \\
\hline $\begin{array}{c}\text { First } \\
\text { author }\end{array}$ & Country & $\begin{array}{c}\text { Year of } \\
\text { publication }\end{array}$ & Study design & $\begin{array}{c}\text { No. of } \\
\text { subjects }\end{array}$ & $\begin{array}{c}\text { Number } \\
\text { with OI }\end{array}$ & $\begin{array}{c}\text { Age range } \\
\text { (years) }\end{array}$ & $\begin{array}{c}\text { Mean age } \\
\text { (years) }\end{array}$ & $\begin{array}{c}\text { Median age } \\
\text { (years) }\end{array}$ & M & F \\
\hline Maines & Italy & 2012 & $\begin{array}{c}\text { Retrospective } \\
\text { Cohort }\end{array}$ & 102 & 102 & $3.1-23.4$ & 12 & x & 47 & 55 \\
\hline Brown & Australia & 2008 & $\begin{array}{c}\text { Retrospective } \\
\text { Cohort }\end{array}$ & 42 & 37 & $\mathrm{X}$ & 8.25 & $\mathrm{x}$ & 28 & 14 \\
\hline Malmgren & Sweden & 2008 & $\begin{array}{c}\text { Retrospective } \\
\text { Cohort }\end{array}$ & 64 & 64 & $0.2-20.9$ & 8.1 & $\mathrm{x}$ & $\mathrm{x}$ & $\mathrm{x}$ \\
\hline Chahine & Canada & 2008 & $\begin{array}{c}\text { Retrospective } \\
\text { Cohort }\end{array}$ & 278 & 221 & $\mathrm{X}$ & $\mathrm{x}$ & 14.7 & 142 & 136 \\
\hline Schwartz & Schwartz & 2008 & Case series & 15 & 15 & $2-16$ & $\mathrm{x}$ & $\mathrm{x}$ & 11 & 4 \\
\hline
\end{tabular}

$\mathrm{OI}=$ osteogenesis imperfecta $\mathrm{X}=$ data not stated in published study $\mathrm{M}=$ male $; \mathrm{F}=$ female . 
Table 2. Summary of intravenous (IV) bisphosphonate use in the 5 studies

\begin{tabular}{cccccc}
\hline $\begin{array}{c}\text { First } \\
\text { author }\end{array}$ & BP used & $\begin{array}{c}\text { Mean duration of } \\
\text { BP use (years) }\end{array}$ & $\begin{array}{c}\text { Range of duration of } \\
\text { use of BP (years) }\end{array}$ & $\begin{array}{c}\text { Mean cumulative } \\
\text { dose of BP }\end{array}$ & $\begin{array}{c}\text { Range of cumulative } \\
\text { dose of BP }\end{array}$ \\
\hline Maines & Neridronate & 6.8 & $1-12.9$ & $1679 \mathrm{mg}$ & $144-5307 \mathrm{mg}$ \\
\hline Brown & $\begin{array}{c}\text { Zoledronate and/or } \\
\text { Pamidronate }\end{array}$ & 6.5 & $\mathrm{X}$ & $\mathrm{x}$ & $29.4-1188 \mathrm{mg}$ \\
\hline Malmgren & Pamidronate & 4.5 & $0.5-12.5$ & $\mathrm{x}$ & $10-40 \mathrm{mg} / \mathrm{m}^{2} \mathrm{over} 5-8 \mathrm{hours}$ \\
\hline Chahine & Pamidronate & 4.6 & $0.3-9$ & $40 \mathrm{mg} / \mathrm{kg}$ & $2.5-81 \mathrm{mg} / \mathrm{kg}$ \\
\hline Schwartz & Pamidronate & 4.6 & $0-21.9$ & $\mathrm{x}$ & $\mathrm{X}$ \\
\hline
\end{tabular}

$\mathrm{BP}=$ bisphosphonates; $\mathrm{X}$ - data not stated in published study.

Table 3. Summary of the 5 studies: method of detecting osteonecrosis of the jaw and proportion of patients who had dental surgery

\begin{tabular}{|c|c|c|}
\hline & \multicolumn{2}{|c|}{ Diagnosis of BRONJ } \\
\hline $\begin{array}{c}\text { First } \\
\text { author }\end{array}$ & Method of detecting BRONJ & $\begin{array}{c}\text { Number of patients who had undergone dental surgery } \\
\text { since commencing IV BP (\%) }\end{array}$ \\
\hline Maines & Clinical examination & $2(1.9)$ \\
\hline Brown & Clinical examination and orthopantanogram & $11(24.4)$ \\
\hline Malmgren & Clinical examination and X-rays in all but 2 children & $22(34.3)$ \\
\hline Chahine & Clinical examination & $113(40.6)$ \\
\hline Schwartz & Clinical examination & $15(100)$ \\
\hline
\end{tabular}

$\mathrm{BRONJ}=$ bisphosphonate-related osteonecrosis of the jaw; IV BP = intravenous bisphosphonates.

were retrospective cohort studies and one [18] was a case series. The number of subjects ranged from 15 to 278 participants. Three studies $[1,16, \underline{18}]$ only included children with OI but 2 studies $[15,17]$ included patients with other bone and connective tissue disorders which also required IV BP therapy. The number of subjects with OI ranged from 15 - 221 children with an age range of 0.2 to 23.4 years. The IV BP used were Neridronate, Zoledronate and/or Pamidronate. Mean duration of IV BP therapy ranged from 4.5 to 6.8 years. All studies used clinical examination as a method of detecting ONJ and 2 studies $[\underline{15}, \underline{16}]$ utilised radiography for diagnosis as well. All studies had patients who had undergone dental surgery during IV BP treatment. Dental surgery included surgical and non-surgical dental extractions and/or manipulation of bone.

Each of the five included studies is described individually below.

\section{Maines et al. 2012 [1]}

This retrospective cohort study of paediatric patients was conducted by the University of Verona, Italy. The study included 102 subjects. Eligibility criteria included OI children or adolescents between 1.2 to 24 years who had received neridronate treatment for at least 1 year. There were 55 female patients aged between 3.7 and 23.1 years (mean 11.8 [SD 5]) of age and 47 male patients between 3.1 and 23.4 years (mean 12.8 [SD 5.2]) of age. All patients had OI - Seventy-five with Type 1, twenty with Type 3 , four with Type 4 and three patients suffered from rarer forms of OI. Type 1 is the mildest form of OI, Type 3 is considered progressive and deforming and Type 4 is deforming but with normal scleras. All patients received the IV BP neridronate. The age IV BP treatment began ranged from 2 months to 19.6 years (mean 5.4 [SD 3.9]). Fifteen patients received IV BP infusions once every 3 - 4 months at a dose of $1 \mathrm{mg} / \mathrm{kg} /$ day for 2 consecutive days. All other patients received IV BP infusions once every $3-6$ months at a dose of $2 \mathrm{mg} / \mathrm{kg} /$ day in a single session. The mean cumulative dose was $1679 \mathrm{mg}$ (range 144 to 5307) and the mean cumulative dose/kg was $50 \mathrm{mg}$ (range 10 to 100). IV BP treatment lasted from 1 to 12.9 years (mean 6.8 [SD 3]). Eight patients stopped the infusions before the analysis. No patients underwent dental extractions. All patients were examined clinically by a dental surgeon. Diagnosis of ONJ was based on finding an area of exposed bone in the maxillofacial region that does not heal within 8 weeks after being identified by a healthcare provider in a patient who is currently receiving or has been exposed to an IV BP and who has not had radiation therapy to the craniofacial region. ONJ was not seen in any patients who were assessed.

\section{Brown et al. 2008 [15]}

This retrospective cohort study included patients treated at the Department of Endocrinology, Royal Children's 
Hospital in Victoria, Australia. The study had 45 subjects. Eligibility criteria included all patients treated with zolendronate or disodium pamidronate (APD). Of the 45 patients, 37 had OI. Three patients were not available for assessment - two had OI and one had McCune Albright syndrome. Mean age at start of treatment was 8.25 (SD 4.1) years. Among 42 patients, 1 received APD only, 4 received zolendronate only and 37 had received both APD and zolendronate. Mean total duration was 6.5 (SD 2.7) years. Mean actual cumulative APD dose was 19.8 (SD 14.8) mg/ $\mathrm{kg}$. Mean actual cumulative zolendronate dose was 0.49 (SD 0.21) $\mathrm{mg} / \mathrm{kg}$. Eleven patients had invasive dental procedures while on IV BP therapy, of which 9 were OI patients. Dental procedures included dental extraction of multiple deciduous, surgical extractions of 2 permanent teeth and surgical exposure of an upper permanent canine. Patients on zolendronate were assessed with a panoramic radiograph and underwent a dental examination by a paediatric dentist. Examination for the presence of non-healing ulcers, exposed bone, periapical or periodontal infections, abnormal mobility of teeth or radiographic radiolucencies in the maxilla or mandible were undertaken and recorded. ONJ was defined as an area of exposed bone in the maxillofacial area that persists for more than 6 weeks. ONJ was not seen in any of the patients assessed.

\section{Malmgren et al. 2008 [16]}

This retrospective cohort study was conducted in the Karolinska Institute, Stockholm, Sweden. The study had 64 subjects. Eligibility criteria included all patients referred from September 1991 to August 2005 to the Swedish National Centre for children and adolescents with OI who had been treated with IV pamidronate for at least 6 months. Age at start of treatment varied from 0.2 to 20.9 years (mean 8.1 ) with a treatment period of 0.5 to 12.5 years (mean 4.5 ). The infusions were given monthly in doses of 10 to $40 \mathrm{mg} / \mathrm{m}^{2}$ over 5 to 8 hours. For the first 3 months, a dose of $10 \mathrm{mg} / \mathrm{m}^{2}$ was given, over the next 3 months $20 \mathrm{mg} / \mathrm{m}^{2}$, followed by 30 to $40 \mathrm{mg} / \mathrm{m}^{2}$ for further treatment. Ten patients continued with oral alendronate in a weekly dose of $70 \mathrm{mg}$. Of these 10 patients, 4 had oral surgery. Thirty-eight dental surgical procedures were performed on 22 of the 64 patients aged 3.4 to 31.9 years after 0.03 to 7.9 years of treatment (mean 3.6, median 3.4). Treatment included tooth extractions and/or surgical removal of teeth in 19 patients of which surgery had been performed on more than one occasion. All patients were examined clinically every 6 months by a dentist and/ or physician. No definition of ONJ was provided in the paper. Oral radiographs were taken in all but 2 patients who were below 3 years old. ONJ was not seen in any of the patients assessed.

\section{Chahine et al. 2008 [17]}

This retrospective cohort study of paediatric patients was conducted in the Shriners Hospital for Children, Montreal, Canada. The study had 278 patients of which 221 patients had OI. There was no clear inclusion and exclusion criterion. The study had no mention of any patients with co-morbidities. Patients received cyclical pamidronate infusions over a median period of 4.6 years (range 1 to 11.2 years). All patients received pamidronate intravenously in cycles of 3 consecutive days. Information on BP therapy could only be obtained from 66 patients. Hence, for theses 66 patients, the total annual pamidronate dose was $9 \mathrm{mg} / \mathrm{kg}$ body weight. The median cumulative dose of pamidronate before dental extraction was $40 \mathrm{mg} / \mathrm{kg}$ (range 2.5 to $81 \mathrm{mg} / \mathrm{kg}$ ). The median duration of pamidronate treatment before dental extraction was 4.6 years. Amongst the 66 patients, a total of 250 teeth extractions had been undertaken - 178 deciduous and 72 permanent teeth. Forty of these 250 teeth required surgical removal with flap elevation, bone removal and tooth sectioning. Clinical examination by a dentist was undertaken for each patient. No definition of $\mathrm{ONJ}$ was provided. A diagnosis of $\mathrm{ONJ}$ was recorded according to the dentist's follow-up records. Follow-up period post dental/surgical extraction ranged from 3 to 1370 days (median 86 days). Follow-up by telephone post dental/surgical extraction ranged from 45 to 3790 days (median 908 days). ONJ was not seen in any of the patients.

\section{Schwartz et al. $2008[\underline{18}]$}

This study was conducted in Montreal Children's Hospital, Canada and included 15 case series. The inclusion criteria included children with OI who had dental extractions at the local dental clinic between 2000 and 2006. A total of 60 teeth were examined. In $65 \%$ of cases (12 sessions, 10 patients), teeth were extracted while the children were receiving IV BP therapy. In $23 \%$ of cases ( 6 sessions, 4 patients), the extractions took place after the completion of treatment. In one patient, the treatment status was unknown. The interval between the end of their medical treatment and their dental surgery ranged from 5.5 months to 2.5 years. This is of interest as BPs are known to be retained in the bone for long periods of time, even years [13]. At the same token, some may argue that delaying dental surgery after cessation of IV BPs, decreases the risk of developing BRONJ. It is unclear which IV BP was used, but there is a suggestion in the discussion 
that pamidronate was the $\mathrm{BP}$ used to treat OI. There is no mention of the duration and cumulative dose of IV BP used. No definition of ONJ was provided either. Patients were followed up at the dental clinic. As no complications were reported in the notes of these 15 patients, the authors inferred from this that no ONJ had occurred.

\section{DISCUSSION}

Epidemiological studies have established a relationship between IV BPs and ONJ in cases of malignant disease. However, the current level of evidence does not prove a direct cause-and-effect relationship between IV BP exposure and ONJ [13]. This is most likely due to the presence of multiple confounding factors which can also contribute to the osteoclastic effect that BPs already cause. This includes concomitant use of corticosteroids for chronic conditions [19], age over 65 years [20,21], radiotherapy and chemotherapy [5-7].

BPs inhibits osteoclast differentiation and induces osteoclast apoptosis, resulting in an imbalance in bone remodelling. However, it is not entirely clear why IV BPs are more positively correlated with ONJ than oral BPs. There is suggestion that it might be related to the bioavailability of the drug. Less than $1 \%$ of the dose of a BP taken orally is absorbed by the gastrointestinal tract, whereas more than $50 \%$ of the dose of IV BPs is bioavailable for incorporation into the bone matrix [22] The half-lives of nitrogen-containing BPs remain the subject of debate $[23,24]$ largely because of technical challenges required to determine bisphosphonate levels in urine and serum. Studies suggest a half-life

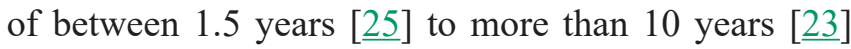
after single-dose IV administration. The half-life is also dependent on the rate of bone turnover, with trabecular bones having a higher rate of turnover than cortical bone and BPs having a higher affinity for bones with higher turnover rates. This partly explains the jaw as a frequent site of BRONJ as the jaw bone consists mainly of alveolar bone which is trabecular in nature and has a high turnover [23-25].

Current data suggests that IV BPs are much more frequently associated with ONJ than oral BPs [26-28]. This has led to the development of different management strategies for patients on oral BPs and those on IV BPs. SDCEP guidelines have separated patients into 2 groups; those on oral BPs and those on IV BPs and describe them as "low" and "high risk" patients for developing BRONJ respectively.

In the high risk category, OI patients are placed together with patients receiving BP therapy for hypercalcaemia secondary to bone metastases, multiple myeloma, concomitant corticosteroid or immunosuppressant therapy. A review of the English literature has revealed 5 relevant studies which have not shown ONJ in OI patients receiving IV BP. This supports the current consensus that a direct cause-and-effect relationship between IV BPs and ONJ is yet to be proven but studies suggest dose-response-duration correlation [30,31].

However, we do know that the occurrence of ONJ appears to be related to cumulative dose, duration of treatment and type of bisphosphonate [29-33], where a positive correlation occurs with higher doses, longer duration of therapy and nitrogen-containing BPs. In the 5 studies reviewed in this study [1, 15-18], the IV BPs used was the more potent nitrogen-containing BPs such as pamidronate, zoledronate and neridronate.

As OI is a genetic disorder diagnosed at a young age, these patients tend to be on life-long regular doses of nitrogen-containing IV BPs. Although causality of IV BPs and ONJ is yet to be proven, there is a strong recognised association between dose, monthly IV BPs and ONJ [13]. In the study of Maines et al. [1], no cases of ONJ were seen in patients who had been treated regularly for nearly 13 years. This is despite the notion that this cohort of patients were still growing and some of were teething, which is a potential risk factor for osteonecrosis due to rapid remodelling of the jaw bone. Maines et al. [1] suggests that one of the possible reasons ONJ is not frequently found in OI patients is that despite the lengthy duration of therapy, low neridronate doses are used. However, Brown et al. [15] reported that the cumulative doses of using pamidronate and zoledronate, when used mostly in OI patients, more closely approximated the doses used in adult patients with malignancy yet none of the patients showed evidence of ONJ. However, the paediatric skeleton cannot be directly compared to the adult skeleton as bone turnover and dynamics is very different and this makes dose comparisons of IV BPs and ONJ very complex [15].

Out of the 5 studies reviewed, 2 of the studies included patients who had diagnoses other than OI. This made data collection and statistical analysis difficult. However, considering that none of the studies revealed any cases of ONJ, the collection of various diagnoses did not influence the final result. In fact, one might argue that despite treatment of other connective tissue disorders other than OI, no cases of ONJ were found. This precludes the notion that the pathophysiology of OI may confer some protection from ONJ.

ONJ is known to occur spontaneously, however, the highest precipitating factor appears to be dental extractions which increase this risk by 10 -fold [15]. Children with OI on long term IV BPs present as a special group of patients who are less likely 
to have any contributory co-morbidity and yet will undergo either natural exfoliation and/or dental/ surgical extraction of teeth. In 4 of the studies, patients had undergone multiple dental surgeries which required exposure, removal and/or manipulation of bone. In one of the study, pulpectomy was carried out in 2 patients and regarded as an "invasive procedure" [1]. However, unlike surgical intervention, pulpectomy is not regarded as a precipitating factor in BRONJ. Despite the osteoclastic effect of nitrogen-containing IV BPs and dental trauma to the jaw, none of these patients showed evidence of ONJ. Although not all the studies specifically mentioned that patients with related co-morbidities were excluded, it is interesting to note that should such patients have been included in the study, and still no cases of ONJ had occurred, this adds weight to the notion that the causality of IV BPs and $\mathrm{ONJ}$ is yet unproven.

Although the direct cause-and-effect relationship of IV BPs and ONJ is questionable, there is a probable link between the dose and duration of treatment. In the treatment of OI, the dose used is less than that used in adults treated for malignancy. However, due to the long term treatment of OI with IV BPs, the cumulative dose can sometimes be as much as that used in adults. A review of the 5 relevant papers did not allow for statistical analysis of the cumulative dose and duration of IV BPs as all the studies were retrospective, the actual dose used for each patient was not always available.

Methodologically, the studies were relatively small (largest included 278 and smallest 15 patients) and it was not possible to judge how representative the study populations were of the hospital populations or general populations of the study areas.Further larger prospective studies are required to ascertain the absolute risk of ONJ in children with OI treated with IV BPs.

\section{CONCLUSIONS}

This brief review has cast doubt on the direct relationship between intravenous bisphosphonates and osteonecrosis of the jaw and questions national guidelines for extractions in patients on bisphosphonates. Currently, osteogenesis imperfecta patients are treated as high risk candidates for developing osteonecrosis of the jaw after dental extractions. However, an extensive literature search has not revealed any evidence of osteogenesis imperfecta patients being at any risk of developing osteonecrosis of the jaw despite dental trauma. More prospective studies need to be carried out to ascertain if a direct cause and effect relationship between intravenous bisphosphonates and bisphosphonaterelated osteonecrosis of the jaw exist in osteogenesis imperfecta patients. This information is critical in the dental management of paediatric and possibly adult patients with metabolic bone disorders who are on intravenous bisphosphonates.

\section{ACKNOWLEDGMENTS AND DISCLOSURE STATEMENTS}

We are grateful to the referees for very helpful and useful comments which undoubtedly improved the final paper. The authors report no conflicts of interest related to this study.

\section{REFERENCES}

1. Maines E, Monti E, Doro F, Morandi G, Cavarzere P, Antoniazzi F. Children and adolescents treated with neridronate for osteogenesis imperfecta show no evidence of any osteonecrosis of the jaw. J Bone Miner Metab. 2012 Jul;30(4):434-8. Epub 2011 Nov 8. [Medline: 22065238] [doi: 10.1007/s00774-011-0331-3]

2. Gatti D, Antoniazzi F, Prizzi R, Braga V, Rossini M, Tatò L, Viapiana O, Adami S. Intravenous neridronate in children with osteogenesis imperfecta: a randomized controlled study. J Bone Miner Res. 2005 May;20(5):758-63. Epub 2004 Dec 20. [Medline: 15824848$]$

3. Glorieux FH, Bishop NJ, Plotkin H, Chabot G, Lanoue G, Travers R. Cyclic administration of pamidronate in children with severe osteogenesis imperfecta. N Engl J Med. 1998 Oct 1;339(14):947-52. [Medline: 9753709] [doi: 10.1056/NEJM199810013391402]

4. Antoniazzi F, Zamboni G, Lauriola S, Donadi L, Adami S, Tatò L. Early bisphosphonate treatment in infants with severe osteogenesis imperfecta. J Pediatr. 2006 Aug;149(2):174-9. [Medline: 16887429] [doi: 10.1016/j.jpeds.2006.03.013]

5. Fedele S, Kumar N, Davies R, Fiske J, Greening S, Porter S. Dental management of patients at risk of osteochemonecrosis of the jaws: a critical review. Oral Dis. 2009 Nov;15(8):527-37. Epub 2009 Jul 13. Review. [Medline: 19619192] [doi: 10.1111/j.1601-0825.2009.01581.x]

6. Mortensen M, Lawson W, Montazem A. Osteonecrosis of the jaw associated with bisphosphonate use: Presentation of seven cases and literature review. Laryngoscope. 2007 Jan;117(1):30-4. Review. [Medline: 17202926] [doi: $10.1097 / 01 . \mathrm{mlg} .0000240885 .64568 .9 \mathrm{e}]$ 
7. Pazianas M, Miller P, Blumentals WA, Bernal M, Kothawala P. A review of the literature on osteonecrosis of the jaw in patients with osteoporosis treated with oral bisphosphonates: prevalence, risk factors, and clinical characteristics. Clin Ther. 2007 Aug;29(8):1548-58. Review. [Medline: 17919538] [doi: 10.1016/j.clinthera.2007.08.008]

8. American Dental Association Council on Scientific Affairs. Dental management of patients receiving oral bisphosphonate therapy: expert panel recommendations. J Am Dent Assoc. 2006 Aug;137(8):1144-50. [Medline: 16873332]

9. Beninati F, Pruneti R, Ficarra G. Bisphosphonate-related osteonecrosis of the jaws (Bronj). Med Oral Patol Oral Cir Bucal. 2013 Sep 1;18(5):e752-8. [Medline: 23722119] [PMC free article: 3790648]

10. Campisi G, Compilato D, Angelo I, Lo Muzio L, Colella G. Spontaneous bisphosphonate-related osteonecrosis of the left hemi-mandible: similarities with phossy jaw. Indian J Dent Res. 2012 Sep-Oct;23(5):683-5. [Medline: 23422621] [doi: 10.4103/0970-9290.107408]

11. Scottish Dental Clinical Effectiveness Programme. Oral health management of patients prescribed biphosphonates: dental clinical guidance. 2011 Apr. Avialable at: http://www.sdcep.org.uk/?o=3120

12. Moher D, Liberati A, Tetzlaff J, Altman DG; PRISMA Group. Preferred reporting items for systematic reviews and metaanalyses: the PRISMA statement. Int J Surg.2010;8(5):336-41. Epub 2010 Feb 18. Erratum in: Int J Surg. $2010 ; 8(8): 658$. [Medline: 20171303] [doi: 10.1016/j.ijsu.2010.02.007]

13. Ruggiero SL, Dodson TB, Assael LA, Landesberg R, Marx RE, Mehrotra B. Task Force on Bisphosphonate-Related Osteonecrosis of the Jaws, American Association of Oral and Maxillofacial Surgeons. American Association of Oral and Maxillofacial Surgeons position paper on bisphosphonate-related osteonecrosis of the jaw - 2009 update. Aust Endod J. 2009 Dec;35(3):119-30. [Medline: 19961450] [doi: 10.1111/j.1747-4477.2009.00213.x]

14. von Elm E, Altman DG, Egger M, Pocock SJ, Gøtzsche PC, Vandenbroucke JP; STROBE Initiative. The Strengthening the Reporting of Observational Studies in Epidemiology (STROBE) statement: guidelines for reporting observational studies. Prev Med. 2007 Oct;45(4):247-51. Epub 2007 Sep 4. Review. [Medline: 17950122] [doi: 10.1016/j.ypmed.2007.08.012]

15. Brown JJ, Ramalingam L, Zacharin MR. Bisphosphonate-associated osteonecrosis of the jaw: does it occur in children? Clin Endocrinol (Oxf). 2008 Jun;68(6):863-7. [Medline: 18221397] [doi: 10.1111/j.1365-2265.2008.03189.x]

16. Malmgren B, Aström E, Söderhäll S. No osteonecrosis in jaws of young patients with osteogenesis imperfecta treated with bisphosphonates. J Oral Pathol Med. 2008 Apr;37(4):196-200. [Medline: 18321345] [doi: $10.1111 / \mathrm{j} .1600-0714.2007 .00607 . \mathrm{x}]$

17. Chahine C, Cheung MS, Head TW, Schwartz S, Glorieux FH, Rauch F. Tooth extraction socket healing in pediatric patients treated with intravenous pamidronate. J Pediatr. 2008 Nov;153(5):719-20. [Medline: 18940358] [doi: 10.1016/j.jpeds.2008.05.003]

18. Schwartz S, Joseph C, Iera D, Vu DD. Bisphosphonates, osteonecrosis, osteogenesis imperfecta and dental extractions: a case series. J Can Dent Assoc. 2008 Jul-Aug;74(6):537-42. [Medline: 18644240]

19. Marx RE, Sawatari Y, Fortin M, Broumand V. Bisphosphonate-induced exposed bone (osteonecrosis/osteopetrosis) of the jaws: risk factors, recognition, prevention, and treatment. J Oral Maxillofac Surg. 2005 Nov;63(11):1567-75. [Medline: 16243172] [doi: 10.1016/j.joms.2005.07.010]

20. Bagan JV, Jimenez Y, Murillo J, Hernandez S, Poveda R, Sanchis JM, Diaz JM, Scully C. Jaw osteonecrosis associated with bisphosphonates: multiple exposed areas and its relationship to teeth extractions. Study of 20 cases. Oral Oncol. 2006 Mar;42(3):327-9. Epub 2005 Nov 4. Review. [Medline: 16275156] [doi: 10.1016/j.oraloncology.2005.08.001]

21. Markiewicz MR, Margarone JE 3rd, Campbell JH, Aguirre A. Bisphosphonate-associated osteonecrosis of the jaws: a review of current knowledge. J Am Dent Assoc. 2005 Dec;136(12):1669-74. [Medline: 16383048]

22. Ezra A, Golomb G. Administration routes and delivery systems of bisphosphonates for the treatment of bone resorption. Adv Drug Deliv Rev. 2000 Aug 31;42(3):175-95. Review. [Medline: 10963835] [doi: 10.1016/S0169-409X(00)00061-2 ]

23. Drake MT, Clarke BL, Khosla S. Bisphosphonates: mechanism of action and role in clinical practice. Mayo Clin Proc. 2008 Sep;83(9):1032-45. Review. [Medline: 18775204] [doi: 10.4065/83.9.1032] [PMC free article: 18775204]

24. Papapoulos SE. Bisphosphonates: how do they work? Best Pract Res Clin Endocrinol Metab. 2008 Oct;22(5):831-47. Review. [Medline: 19028359] [doi: 10.1016/j.beem.2008.07.001]

25. Lin JH. Bisphosphonates: a review of their pharmacokinetic properties. Bone. 1996 Feb;18(2):75-85. Review. [Medline: $\underline{8833200]}$

26. Durie BG, Katz M, Crowley J. Osteonecrosis of the jaw and bisphosphonates. N Engl J Med. 2005 Jul 7;353(1):99-102; discussion 99-102. [Medline: 16000365] [doi: 10.1056/NEJM200507073530120]

27. Marx RE, Cillo JE Jr, Ulloa JJ. Oral bisphosphonate-induced osteonecrosis: risk factors, prediction of risk using serum CTX testing, prevention, and treatment. J Oral Maxillofac Surg. 2007 Dec;65(12):2397-410. [Medline: 18022461] [doi: 10.1016/i.joms.2007.08.003]

28. Bamias A, Kastritis E, Bamia C, Moulopoulos LA, Melakopoulos I, Bozas G, Koutsoukou V, Gika D, Anagnostopoulos A, Papadimitriou C, Terpos E, Dimopoulos MA. Osteonecrosis of the jaw in cancer after treatment with bisphosphonates: incidence and risk factors. J Clin Oncol. 2005 Dec 1;23(34):8580-7. [Medline: 16314620] [doi: 10.1200/JCO.2005.02.8670]

29. Woo SB, Hellstein JW, Kalmar JR. Narrative [corrected] review: bisphosphonates and osteonecrosis of the jaws. Ann Intern Med. 2006 May 16;144(10):753-61. Review. Erratum in: Ann Intern Med. 2006 Aug 1;145(3):235. [Medline: 16702591] [doi: 10.7326/0003-4819-144-10-200605160-00009] 
30. Khosla S, Burr D, Cauley J, Dempster DW, Ebeling PR, Felsenberg D, Gagel RF, Gilsanz V, Guise T, Koka S, McCauley LK, McGowan J, McKee MD, Mohla S, Pendrys DG, Raisz LG, Ruggiero SL, Shafer DM, Shum L, Silverman SL, Van Poznak CH, Watts N, Woo SB, Shane E. American Society for Bone and Mineral Research. Bisphosphonate-associated osteonecrosis of the jaw: report of a task force of the American Society for Bone and Mineral Research. J Bone Miner Res. 2007 Oct;22(10):1479-91. [Medline: 17663640] [doi: 10.1359/jbmr.0707onj]

31. Mavrokokki T, Cheng A, Stein B, Goss A. Nature and frequency of bisphosphonate-associated osteonecrosis of the jaws in Australia. J Oral Maxillofac Surg. 2007 Mar;65(3):415-23. [Medline: 17307586] [doi: 10.1016/j.joms.2006.10.061]

32. Dannemann C, Grätz KW, Riener MO, Zwahlen RA. Jaw osteonecrosis related to bisphosphonate therapy: a severe secondary disorder. Bone. 2007 Apr;40(4):828-34. Epub 2007 Jan 22. [Medline: 17236837] [doi: $10.1016 /$ i.bone.2006.11.023]

33. Olutayo J, Agbaje JO, Jacobs R, Verhaeghe V, Valde VF, Vinckier F. Bisphosphonate-Related Osteonecrosis of the Jaw Bone: Radiological Pattern and the Role of CBCT in Early Diagnosis. J Oral Maxillofac Res 2010 (Apr-Jun);1(2):e3. URL: http://www.ejomr.org/JOMR/archives/2010/2/e3/e3ht.htm

\section{To cite this article:}

Hennedige AA, Jayasinghe J, Khajeh J, Macfarlane TV. Systematic Review on the Incidence of Bisphosphonate Related Osteonecrosis of the Jaw in Children Diagnosed with Osteogenesis Imperfecta.

J Oral Maxillofac Res 2013;4(4):e1

URL: http://www.ejomr.org/JOMR/archives/2013/4/e1/v4n4e1ht.pdf

doi: $\underline{10.5037 / j o m r .2013 .4401}$

Copyright (C) Hennedige AA, Jayasinghe J, Khajeh J, Macfarlane TV. Published in the JOURNAL OF ORAL \& MAXILLOFACIAL RESEARCH (http://www.ejomr.org), 1 January 2014.

This is an open-access article, first published in the JOURNAL OF ORAL \& MAXILLOFACIAL RESEARCH, distributed under the terms of the Creative Commons Attribution-Noncommercial-No Derivative Works 3.0 Unported License, which permits unrestricted non-commercial use, distribution, and reproduction in any medium, provided the original work and is properly cited. The copyright, license information and link to the original publication on (http://www.ejomr.org) must be included. 